\title{
POLA PENGASUHAN ANAK PADA KOMUNITAS ADAT GIRI JAYA (Suatu Tinjauan Sosial Budaya)
}

\author{
Oleh Nina Merlina \\ Balai Pelestarian Sejarah dan Nilai Tradisional Bandung \\ Jln. Cinambo No. 136 Ujungberung Bandung \\ Email: merlinanina@ymail.com
}

\section{Abstrak}

Pada prinsipnya, pola pengasuhan anak merupakan proses sosialisasi. Pola pengasuhan anak pada komunitas adat Giri Jaya Padepokan, menjadi bagian dari budaya masyarakat tersebut. Keluarga sebagai unit sosial terkecil, merupakan tempat seorang anak tumbuh dan berinteraksi. Keluarga juga memegang peran yang sangat penting dalam proses sosialisasi bagi anak-anak ketika ia beranjak dewasa dan bergaul dengan individu lainnya di dalam maupun di luar lingkungan masyarakat. Pola pengasuhan ini, pada gilirannya akan berperan besar dalam pembentukan karakter anak dalam perkembangan berikutnya.

Secara umum, tujuan penelitian ini adalah untuk mengungkap dan mengetahui salah satu aspek kebudayaan mengenai kehidupan sosial budaya, terutama mengenai sistem dan pola pengasuhan anak pada komunitas adat Giri Jaya Padepokan. Metode yang digunakan dalam penelitian ini adalah metode deskriptif dengan penelaahan data yang bersifat kualitatif.

Kata kunci: interaksi sosial, pola pengasuhan anak, komunitas adat.

Abstract
Nurturing is basically a process of socialization. As the smallest social unit, family plays the main role in nurturing their children. Family is the place where children are grown up and interact with other members of the family. They also learn how to build character and face another environment in their future life.

The purpose of this research is to reveal social life in a traditional community of Padepokan Giri Jaya, focusing on their nurturing pattern. A desctiptive method was conducted along with qualitative data review.

Keywords: social interaction, pattern of parenting, local cumunnity.

\section{A. PENDAHULUAN}

Sejak masa kanak-kanak manusia telah mengalami suatu proses enkulturasi, proses ini dimulai sejak masa kelahiran dan terus berlanjut hingga meninggal. Enkulturasi merupakan proses penanaman nilai kebudayaan dari satu generasi ke generasi berikutnya, dimana dalam prosesnya, enkulturasi dilakukan dengan berbagai medium, namun medium yang paling efektif adalah pendidikan. Pendidikan di dalam keluarga tidak lain adalah memberikan 
kesempatan kepada individu untuk memperoleh pengalaman-pengalaman dan menyesuaikan diri dengan kehidupan keluarga tersebut dan merupakan bekal dalam lingkungan masyarakat kelak.

Suatu hal yang tidak bisa dipungkiri, bahwa manusia adalah makhluk sosial yang sejak lahir terus menerus dipengaruhi dan tergantung dari manusia lainnya di dalam lingkungan sosialnya. Sejak lahir ke dunia, ia membutuhkan bantuan dan pergaulan dengan orang lain untuk memenuhi kebutuhannya demi kelangsungan hidupnya. Hubunganhubungan yang terjadi di dalam keluarganya memberikan pengalamanpengalaman baru dan cara-cara berlaku sebagai bekal hidup di masyarakat kelak. Berkembang tidaknya tata kehidupan suatu masyarakat dapat dilihat antara lain dari pola pengasuhan anak yang ada pada masyarakat tersebut.

Pola pengasuhan anak pada masyarakat, merupakan faktor yang sangat penting dan mendasar. Pola pengasuhan anak merupakan bagian dari proses sosialisasi. Dalam proses ini, seorang individu akan dibimbing dan diarahkan oleh orang tuanya untuk membentuk jati dirinya menjadi seorang anggota masyarakat, yang mampu berpikir dan bertindak sesuai norma dan nilai sosial budaya yang berlaku pada masyarakat tersebut. Sebagai bagian dari proses sosialisasi, pola pengasuhan anak dalam keluarga berlaku pada setiap masyarakat. Pola pengasuhan anak pada setiap masyarakat tidak bisa terlepas dari fungsinya yaitu menyiapkan seorang anak untuk menjadi warga masyarakat.
Pola pengasuhan anak merupakan satu upaya agar masyarakat dan kebudayaan dapat terpelihara terus, ide-ide yang ditanamkan kepada warga baru ini harus sesuai dengan yang berlaku pada masyarakat dan kebudayaannya. Proses pewarisan kebudayaan ini akan dimulai pertama kali di dalam lingkungan keluarga yang merupakan unit sosial terkecil dalam masyarakat.

Setiap kelompok sosial dalam masyarakat, khususnya keluarga akan membekali anak-anaknya agar mampu meneruskan pranata-pranata yang menjadi ciri keluarga dan masyarakat. Setiap suku bangsa dan golongan akan mengembangkan sistem pendidikan informal dalam keluarganya sesuai dengan cara dan modelnya masingmasing dan mengacu pada nilai budaya yang dianut.

Pengasuhan anak tidak hanya meliputi mendidik, menjaga, merawat, serta membimbing anak-anak dalam keluarga, tetapi juga mendidik kesopanan, saling menghormati, disiplin, serta kebersihan dan kesehatan. Dalam hal ini sosialisasi adalah proses seorang individu berinteraksi dengan sesamanya.

Berbicara mengenai pola pengasuhan anak, pada komunitas adat Giri Jaya, pola pengasuhan anak sangat dipengaruhi oleh adat istiadat dan taraf hidup yang mungkin berbeda dengan komunitas adat dan laiannya. Hal ini disebabkan pola pengasuhan anak tidak sama bentuknya pada setiap keluarga ataupun setiap suku bangsa. Pola pengasuhan anak sangat dipengaruhui oleh faktor-faktor kebudayaan yang mendukungnya, seperti faktor pendidikan, faktor stratifikasi sosial, faktor mata pencaharian, dan faktor 
kebiasaan dalam tiap keluarga ataupun suku bangsa

Sifat kebudayaan adalah dinamis, maka tidak menutup kemungkinan akan terjadi perubahan dalam setiap aspek kebudayaan tersebut, termasuk salah satunya adalah pola pengasuhan anak. Hal ini dimungkinkan adanya perubahan orientasi yang disebabkan oleh berbagai faktor, baik itu faktor dari dalam atau intern keluarga maupun faktor ekstern yang ada di lingkungan masyarakat.

Dalam Masyarakat Tradisional, pendidikan dikembangkan melalui lembaga adat dan dalam lingkungan keluarga, dan nilai-nilai yang menjadi acuan sikap dan tingkah laku bagi masyarakat sudah baku. Tapi sekarang ini dengan semakin majunya teknologi dan adanya interaksi dengan masyarakat lainnya tentu mengalami perubahan-perubahan dalam sistem nilai, aturan-aturan, tingkah laku dalam pengasuhan anak. Hal ini juga terkait dengan perubahan lingkungan geografis yang juga mempengaruhi kebudayaan nya yang berdampak pada pola pengasuhan anak.

Dari berbagai uraian di atas, dapat ditarik suatu permasalahan dalam penelitian ini yaitu; 1) Bagaimana pola pengasuhan anak pada komunitas adat Giri Jaya melalui pola tingkah laku yang berhubungan dengan kehidupan mereka, 2) Bagaimana pola pengasuhan anak pada komunitas adat Giri Jaya Padepokan ditinjau dari segi sosial budaya? 3) Langkah-langkah atau

\footnotetext{
${ }^{1}$ Alif Futaqi "Pola Pengasuhan Anak Suku Marind-Anim Kabupaten Merauke, Propinsi Papua.
}

tahapan-tahapan apa saja yang dilakukan oleh masyarakat tersebut dalam pola pengasuhan anak di Kasepuhan Giri Jaya Padepokan? 4) Apakah masyarakat Desa Giri Jaya Padepokan masih berorientasi pada kebudayaan komunitas adat yang bersangkutan secara utuh?

Secara umum, tujuan penelitian ini adalah untuk mengetahui salah satu aspek kebudayaan mengenai kehidupan sosial budaya komunitas adat yang ada di Desa Giri Jaya, mereka menamakan diri dengan Komunitas Adat Padepokan Giri Jaya Padepokan terutama mengenai "Bagaimana Pola Pengasuhan Anak pada Komunitas Adat Giri Jaya Padepokan?" Adapun tujuan khususnya adalah untuk mendokumentasikan data tentang Kajian Sosial Budaya mengenai Pola Pengasuhan Anak yang berlaku pada Komunitas Adat Giri Jaya Padepokan.

Ruang lingkup dalam penelitian ini dibagi ke dalam bagian, yakni ruang lingkup permasalahan dan ruang lingkup wilayah. Mengingat begitu luasnya peristiwa budaya yang dihadapi oleh suatu masyarakat, maka dalam penelitian ini, permasalahan dibatasi dengan hanya melihat hal-hal yang sangat berkaitan dan relevan dengan permasalahan, yakni Pola Pengasuhan Anak.

Adapun ruang lingkup wilayah dalam penelitian ini adalah Giri Jaya Padepokan, yang terletak di Desa Giri Jaya, Kecamatan Cidahu, Kabupaten Sukabumi, Provinsi Jawa Barat.

Adapun landasan teori dan konsep dasar yang mendasari dilakukannya penelitian ini adalah teori tentang interaksi sosial, hubungan sosial dan sistem pengasuhan itu sendiri. Karena berbicara pola 
pengasuhan, tidak lepas dari pembicaraan mengenai interaksi sosial.

Konsep yang mendasari dilakukannya penelitian ini adalah proses sosialisasi, interaksi dan hubungan sosial. Hal ini disebabkan, pengasuhan anak merupakan bagian yang sangat penting dari proses sosialisasi yang dapat berpengaruh terhadap kelakuan si anak jika dia sudah dewasa. Hal ini juga terkait dengan kelakuan manusia yang bervariasi bergantung pada masyarakat yang dibicarakan sebagai pendukung kebudayaan tersebut. Variasi-variasi itu diteruskan dari satu generasi ke generasi yang berikutnya melalui 'sosial learning'. Pengaruh kebudayaan pada kepribadian anak sangat besar dengan ciri-ciri kepribadian anak yang berkebudayaaan berlainan tidaklah sama. Hal ini disebabkan oleh sistem nilai kebudayaan masing-masing yang berbeda sehingga cara mengasuh dan mendidiknya pun berbeda.

\section{B. HASIL DAN BAHASAN}

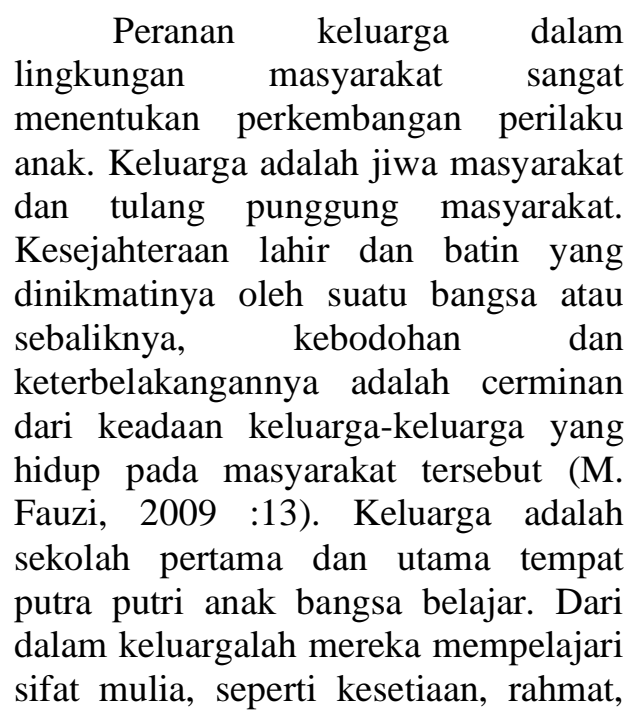

kasih sayang, ghirah (kecemburuan positif) dan sebagainya.

Seorang individu setelah lahir, kemudian ia akan mengenal lingkungan di luar dirinya baik itu lingkungan benda-benda maupun manusia di sekitarnya untuk pertama kali adalah melalui keluarga. Proses sosialisasi seseorang sangat ditentukan oleh peranan lingkungan sosial dimana dia berada. Proses sosialisasi seseorang tidak bisa dilepaskan dengan pola interaksi di lingkungannya. Proses interaksi seseorang dalam lingkungan masyarakat tidak hanya terjadi antara seseorang dengan anggota keluarga inti saja, melainkan dengan orang lainnya yang ada di lingkungan masyarakat sekitarnya. Proses sosialisasi ini hampir berlaku pada setiap orang di dalam lingkungan keluarganya. Proses sosialisasi merupakan proses internalisasi atau penanaman nilai-nilai budaya, dan terjadi terutama di dalam lingkungan keluarga. Proses tersebut adalah proses dimana seseorang mendapatkan pendidikan pertama dan utama di lingkungan keluarga. Dengan kata lain, sebelum seseorang masuk dalam lingkungan yang lebih luas atau lingkungan masyarakat bahkan bangsa dan negara, lingkungan keluarga merupakan tempat pertama kali terjadinya proses sosialisasi.

Keluarga dan berkeluarga merupakan satu gejala sosial yang bersifat universal, artinya dalam semua masyarakat akan ditemukan gejala ini. Setiap orang dengan senirinya akan masuk dalam keluarga tertentu, dan merupakan bagian satu masyarakat yang lebih besar. Setiap orang mempunyai status tertentu dalam keluarga baik keluarga dalam arti 
sempit maupun keluarga dalam arti luas. Dalam keluarga akan terbentuk suatu pola hubungan di antara anggotaanggotanya. Diantaranya adalah hubungan antara ayah dan ibu, hubungan antara ayah dan anak, hubungan antara ibu dan anak, dan hubungan dengan anggota keluarga lain yang tinggal bersama dalam satu rumah.

Berbicara mengenai perkawinan dan rumah tangga, tidak lepas dari pembicaraan mengenai adat menetap setelah menikah. Hal ini berkaitan dengan adat menetap setelah menikah pada komunitas adat Giri Jaya Padepokan. Pada umumnya, komunitas adat Giri Jaya Padepokan menikah di lingkungan keluarga perempuan, dan adat menetap setelah menikah di pihak perempuan atau matri lokal. Mereka akan hidup mandiri, apabila mereka sudah mampu, dan mereka akan pindah ke rumah yang baru sebagai tempat tinggal baru. Sistem perkawinan pada komunitas adat Giri Jaya Padepokan pada umumnya adalah matri lokal yang kemudian neo lokal. Anak-anak pada umumnya tinggal bersama orang tuanya, oleh sebab itu, sejak kecil yang mengurus dan merawat anak adalah seorang ibu. Peran ibu dalam urusan keluarga sangat sentral, terutama urusan internal rumah. Adat menetap pada komunitas adat Giri Jaya Padepokan tidak mutlak harus matrilokal atau neolokal, oleh sebab itu dalam implementasinya bersifat fleksibel. Dengan demikian, tidak ada aturan baku dalam hak adat "menetap bersama orang tua" atau "langsung terpisah setelah menikah" di Desa Giri Jaya Padepokan.

Adat menetap setelah menikah berpengaruh terhadap sikap dan perilaku anggota keluarga yang melakukan. Hal ini berpengaruh terhadap kedewasaan anggota keluarga tersebut. Sebagian besar komunitas adat Giri Jaya Padepokan melakukan sistem adat menetap setelah menikah itu secara matrilokal, jadi dalam satu rumah ada beberapa keluarga, karena tidak menutup kemungkinan dalam satu rumah tangga tersebut ada beberapa orang anak yang sudah menikah, tetapi masih tinggal bersama orang tuanya. Dengan kata lain, "adat menetap setelah menikah" begitu juga "usia menikah pada seseorang", sangat berpengaruh terhadap pola asuh. Karena seperti sudah dikatakan di atas, bahwa adat menetap dan usia menikah berpengaruh terhadap kedewasaan dan pertumbuhan seseorang. Dengan begitu, dalam satu rumah tangga yang terdiri atas lebih dari satu keluarga, bisa dikatakan sebagai extended family atau keluarga luas. Hal ini mempengaruhi pada sistem dan pola pengasuhan anak.

Hubungan antara ayah dengan ibu sangat menentukan perilaku anak dalam kehidupannya, baik di dalam lingkungan keluarga maupun di lingkungan masyarakat. Orang tua adalah contoh bagi anak-anaknya dan anggota keluarga yang lain di dalam rumah. Orang tua adalah contoh bagi anak-anaknya, oleh sebab itu, mereka harus berperilaku sesuai dengan nilainilai yang berlaku. Dengan demikian anak-anak akan meniru perbuatan orang tuanya.

Hal ini bisa dilihat dalam kehidupan salah seorang warga komunitas adat Giri Jaya Padepokan. Pada waktu anak-anak masih kecil, hubungan mereka (anak-anak) dengan ayahnya sangat dekat, namun menjelang dewasa bahkan setelah 
dewasa, mereka (anak-anaknya) tidak akrab atau tidak begitu dekat lagi dengan bapaknya. Anak-anak merasa segan, apabila harus berhadapan dengan ayahnya. Mereka lebih dekat kepada ibunya. Sikap segan mereka bukan berarti mereka takut, namun lebih disebabkan oleh status sang ayah yang menjadi pimpinan atau sesepuh di wilayah tersebut. Oleh masyarakat sekitar, ayahnya sangat disegani dan dihormati, dengan sendirinya mereka pun merasa segan kepada ayahnya. Kedekatan anak-anak dengan ibunya disebabkan keseharian mereka (anakanak) yang selalu dekat dengan ibu. Namun begitu, posisi bapak tetap dominan. Bagaimana pun seorang bapak adalah pimpinan dalam suatu keluarga $^{2}$.

Kedekatan anak juga bisa dilihat dari hubungan mereka dalam lingkungan keluarga dengan anggota keluarga yang lainnya. Baik itu hubungan antara kakak dengan adiknya maupun hubungan antaranggota keluarga lainnya. Dalam hal kedekatan ini memungkinkan ada hubungan atau interaksi antaranggota keluarga dalam satu rumah yang di dalamnya terdiri atas beberapa keluarga, dalam hal ini keluarga besar. Dalam kehidupan suatu keluarga, hubungan antaranggota relatif akrab. Tiap orang merasa memiliki apa yang ada di dalam lingkungan keluarga tersebut.

Kedekatan si anak dengan orang tuanya merupakan refleksi sikap anak terhadap orang tuanya, dalam arti perilaku anak diwarnai oleh karena keseringan dan kebersamaan si anak

2 Hasil wawancara dengan istri ketua adat Giri Jaya Padepokan. dengan orang tua, baik itu ayah, ibu, bahkan anggota keluarga lain seperti nenek, paman, bibi, bahkan pembantu rumah tangga. Apabila anak memperoleh kedekatan dengan keluarga lain, selain ayah dan ibu, maka yang melekat pada diri anak tidak dominan pengaruh dari ayah dan ibunya. Hal tersebut akan menimbulkan perilaku lain dari anak tersebut yang berbeda dengan perilaku ayah dan ibunya. Hal itu muncul karena adanya pengaruh dari anggota keluarga lain yang bisa mewarnai pola perilaku anak tersebut.

Hubungan anak-anak dalam satu keluarga juga bisa dilihat dari perilaku setiap anggota keluarga tersebut. Apalagi di dalam satu rumah tangga yang terdiri atas beberapa keluarga, yang tidak hanya ayah ibu dan anakanaknya saja, melainkan juga keluarga lain, seperti nenek, paman dan anggota keluarga lainnya. Kondisi dan suasana seperti tersebut di atas, berpengaruh terhadap pola asuh anak dalam keluarga tersebut. Sebagai contoh, kasih sayang dan perhatian seorang nenek kepada cucunya biasanya berlebihan dibandingkan dengan kasih sayang ayah dan ibu terhadap anaknya. Seorang nenek biasanya cenderung bersifat nyaah dulang terhadap cucunya, hal ini dapat memunculkan perilaku manja pada anak, walaupun sebenarnya tidak semua nenek bersikap seperti itu dalam memperlakukan cucunya. Terkadang, peranan seorang nenek sangat membantu dalam mengurus anak-anak, terutama pada saat ayah dan ibu tidak ada di rumah, nenek dapat menggantikan peran ayah dan ibu sebagai orang tua di rumah. 
Gambar 1

Nenek dan cucunya

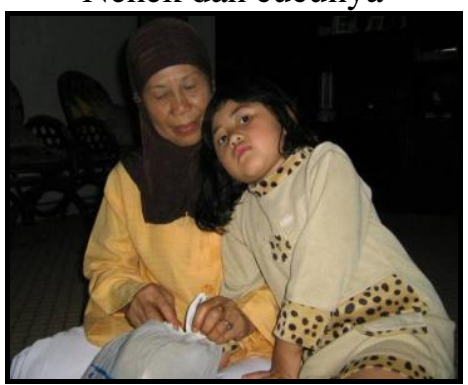

Sumber : Dokumen Penelitian 2009

Seseorang akan mengenal lingkungan di luar dirinya pertama kali melalui keluarga. Cepat atau lambat proses sosialisasi seseorang sangat ditentukan oleh peranan lingkungan keluarga dimana anak berada. Proses interaksi seorang anak dalam keluarga tidak hanya terjadi antara seorang anak dengan anggota keluarga inti saja, melainkan terjadi juga interaksi dengan orang-orang sekitarnya. Oleh sebab itu, di bawah ini diuraikan tentang polapola interaksi antara anggota keluarga. Interaksai tersebut antara, ayah dengan anak-anaknya, ibu dengan anak anaknya, atau antarsaudara kandung dalam keluarga tersebut. Oleh sebab itu, tidak heran apabila peranan keluarga dan lingkungan sangat menentukan perkembangan perilaku anak.

Komunitas adat Giri Jaya Padepokan mengenal adanya pembagian tugas dalam mengatur kehidupan keluarganya tersebut. Pembagian tugas tersebut biasanya ditentukan oleh faktor gender atau jenis kelamin dan usia. Secara umum, seorang bapak atau ayah adalah pencari nafkah dan seorang ibu atau perempuan adalah mengurus urusan dalam rumah tangga. Namun begitu, tidak menutup kemungkinan bahwa seorang bapak juga ikut mengurus anak-anak di rumah, begitu pula dengan ibu, tidak menutup kemungkinan si ibu juga ikut mencari nafkah, untuk menambah penghasilan. Di lingkungan komunitas adat Giri Jaya Padepokan ditemukan seorang bapak atau ayah mengasuh anaknya sambil berjualan keliling atau mengasuh anak sambil mencari nafkah.

Salah satu fungsi keluarga adalah sebagai media atau wahana pendidikan. Seorang ayah atau bapa akan berusaha mendidik anak-anaknya dalam berbagai situasi sesuai dengan kemampuannya. Tanggung jawab ayah tentang pendidikan dan pembinaan budaya terhadap anak sebenarnya sama dengan ibu dan anggota lainnya.

Adapun hubungan dengan ibu masih terus berlanjut sampai si anak dewasa. Hal ini sangat memungkinkan, karena kebutuhan anak lebih banyak dipenuhi melalui ibu, sehingga kedekatan terhadap ibu masih sangat memungkinkan, karena kebutuhan anak lebih banyak dipenuhi melalui ibu, sehingga kedekatan terhadap ibu masih berlangsung sampai anak dewasa.

Di dalam lingkungan keluarga, pada komunitas adat Giri Jaya Padepokan seorang individu diajarkan tata krama dan perilaku-perilaku yang sesuai dengan nilai-nilai dan norma serta mengarah ke hal-hal yang positif, baik dan bagus. Di dalam keluarga juga ditanamkan sistem pembagian tugas secara proporsional, baik untuk lakilaki maupun perempuan. Walaupun hal ini berlaku umum, namun tidak semua keluarga dapat menanamkan hal-hal yang sama dilihat dari segi kualitas perilaku maupun pembiasaan serta pengembangan diri di dalam lingkungan keluarganya. 
Sopan santun atau tata krama dalam kehidupan suatu keluarga dan masyarakat umumnya merupakan hal yang pokok dan perlu ditanamkan dan dibina sejak dini oleh orang tua kepada anaknya. Mengingat pentingnya hal tesebut, maka orang tua akan berusaha menggunakan berbagai cara sebagai medianya. Adakalanya orang tua menyampaikannya dengan ungkapanungkapan atau pantangan-pantangan. Ungkapan-ungkapan dan pantanganpantangan yang disampaikan oleh orang tua menjadi suatu kearifankearifan.

Hal ini menunjukkan bahwa penerapan nilai-nilai dan norma yang diperoleh di lingkungan keluarga berbeda antara keluarga yang satu dengan keluarga yang lainnya. Sistem penanaman nilai-nilai dan normanorma atau internalisasi ini merupakan bagian penting dari pola pengasuhan anak, khususnya di lingkungan keluarga. Pola pengasuhan anak bersifat universal, dalam artian bahwa sistem pola pengasuhan anak ini ada dan dikenal di setiap lingkungan keluarga di manapun berada, termasuk di lingkungan komunitas adat. Apabila diamati dengan seksama, perbedaan itu tidak begitu signifikan, karena hanya caranya saja yang berbeda, dalam hal ini faktor lingkungan sangat berpengaruh, baik itu lingkungan geografis atau tempat tinggal dan faktor lingkungan sosial budaya masyarakat dimana keluarga itu berada.

Hal tersebut terjadi juga pada komunitas adat. Pada komunitas adat dikenal pula sistem atau pola pengasuhan anak dalam keluarga, walaupun mungkin berbeda dengan keluarga yang berada pada masyarakat di lingkungan perkotaan. Pada hakekatnya sistem penanaman nilainilai dan norma atau pola pengasuhan anak dalam keluarga berlaku universal di setiap masyarakat, baik di lingkungan masyarakat pedesaan maupun di lingkungan masyarakat perkotaan. Akan tetapi pada dasarnya banyak juga perbedaan dalam pelaksanaan pola pengasuhan anak. Hal tersebut disebabkan oleh perbedaan budaya atau kultur yang mewarnai dan melekat pada setiap kelompok masyarakat dimana mereka tinggal.

Menikah pada usia muda berpengaruh terhadap pola pengasuhan anak dalam lingkungan keluarga, pada komunitas adat Giri Jaya. Menikah pada usia muda merupakan hal yang sudah lumrah pada masyarakat pedesaan. Begitu pula dengan komunitas adat Giri Jaya. Oleh karena itu proses penanaman nilai dalam keluarga sesuai dengan kondisi pada waktu itu.

Belajar bahasa pada hakikatnya adalah belajar berkomunikasi. Mengajarkan anak berbahasa merupakan salah satu bentuk sistem penanaman nilai-nilai dan norma di dalam keluarga. Dengan mengajarkan anak menggunakan bahasa daerah atau bahasa Sunda sebagai bahasa ibu, apalagi bahasa yang digunakan adalah bahasa Sunda halus bagi sebagian orang tua di daerah penelitian, merupakan suatu pengenalan perilaku tata krama, sopan santun, atau budi pekerti yang baik. Namun begitu, tidak semua anak mendapat pembelajaran atau diajari bahasa Sunda yang halus. Banyak di antara mereka yang sehariharinya menggunakan bahasa Sunda kasar, hal ini disebabkan bahasa yang 
mereka dapatkan dari orang tuanya adalah bahasa Sunda kasar. Bahasa Sunda kasar tersebut dijadikan sebagai bahasa pergaulan sehari-hari oleh sebagian anak-anak di lingkungan masyarakat, yang ditemukan di daerah penelitian. Padahal dengan bertutur kata dan bahasa yang baik serta bagus, dapat menunjukkan bahwa si anak bisa bersikap santun.

Sebagian besar masyarakat Giri Jaya adalah masyarakat Sunda, oleh karena itu bahasa yang digunakan dalam kehidupan sehari-hari adalah Bahasa Sunda, baik itu di lingkungan rumah atau dalam pergaulan sehari-hari dengan masyarakat di luar rumah. Terdapat juga sebagian warga yang sehari-harinya menggunakan bahasa Indonesia. Hal tersebut terjadi karena pengaruh pergaulan di luar rumah atau pengaruh tayangan televisi. Mereka yang sehari-harinya menggunakan bahasa Indonesia adalah anak-anak muda atau remaja. Walaupun orang tuanya berbahasa Sunda, tetapi anakanak atau remaja ada yang menggunakan bahasa Indonesia. Bagi mereka bahasa Indonesia bukan saja bahasa resmi yang digunakan di lingkungan formal atau resmi, tetapi juga sebagai bahasa pergaulan.

Dalam hal penggunaan bahasa sehari-hari, dituturkan oleh seorang ibu yang mengatakan bahwa dia sebagai ibu menggunakan bahasa Sunda kepada anak-anaknya, tapi anak-anaknya malah menggunakan bahasa Indonesia dalam kehidupan sehari-harinya. Bagi si ibu, dengan menggunakan bahasa Sunda, katanya, hubungan dengan anak terasa lebih dekat dan akrab. Secara umum sebenarnya, bahasa yang digunakan adalah bergantung dengan lawan bicara atau orang yang diajak bicara. Apabila yang menggunakan bahasa untuk berkomunikasi tersebut tersebut adalah orang tua kepada anak, biasanya bahasa yang digunakan adalah bahasa sedang atau kasar. Apabila ada tamu, maka orang tua akan menggunakan bahasa Sunda yang halus dalam berkomunikasi.

Pada sebagian anak-anak ada juga yang menggunakan bahasa Sunda sedang atau bahkan bahasa Sunda kasar. Bagi sebagian anak-anak/remaja sepertinya mengalami kesulitan untuk menggunakan bahasa Sunda yang halus. Oleh karena itu, mereka kadang menggunakan bahasa Indonesia dalam kehidupan sehari-harinya. Bagi orang tua pada umumnya menggunakan bahasa Sunda, bagi mereka yang menggunakan bahasa Sunda sebenarnya merupakan salah satu proses pembelajaran atau cara mendidik anak dengan mengenalkan budaya daerah.

Seperti telah dipaparkan terdahulu bahwa setiap orang dalam keluarga tentunya berbeda dalam mendidik anak, hal ini disebabkan oleh pendekatan yang dilakukan oleh anggota keluarga terutama orang tua, proses pendidikan itu sendiri terjadi dalam kehidupan sehari-hari. Masyarakat pada umumnya membedakan pendekatan yang dilakukan orang tua terhadap anak kecil usia antara 0 tahun sampai 5 tahun (balita) dan kanak-kanak antara usia 6 tahun dan usia 9 tahun, begitu juga kepada anak yang sudah menjelang remaja sekitar usia 10 sampai usia 15 tahun.

Pendidikan merupakan salah satu bagian dari penanaman nilai dan norma yang paling mendasar. Karena pendidikan adalah usaha sadar dan 
terencana untuk mewujudkan suasana belajar dan proses pembelajaran agar peserta didik secara aktif mengembangkan potensi dirinya untuk memiliki kekuatan spiritual keagamaan, pengendalian diri, kepribadian, kercerdasan, akhlak mulia, serta keterampilan yang diperlukan dirinya, masyarakat, bangsa dan negara.

Di lingkungan komunitas adat Giri Jaya, ada sebuah lembaga pendidikan PAUD, yaitu Pendidikan Anak Usia Dini. PAUD merupakan tempat berlangsungnya proses penanaman nilai-nilai atau sosialisasi bagi anak-anak Balita. Seperti halnya sebuah sekolah, lembaga ini juga ditunjang oleh sarana dan prasarana yang mendukung berlangsungnya kegiatan proses penanaman nilai-nilai tersebut. Seperti adanya gedung, tempat berlangsungnya proses belajar dan juga guru atau pembimbing dalam proses penanaman nilai-nilai. Bagi orang tua yang memasukkan anakanaknya ke lembaga ini, merasa senang karena dengan memasukkan anakanaknya, mereka seolah menitipkan anak dan mereka merasa dibantu dalam hal mendidik anak-anaknya. Dalam kegiatan PAUD (Pendidikan Anak Usia Dini), diajarkan perilaku-perilaku yang baik atau tata krama yang sesuai untuk anak-anak balita. Dengan memasukkan anak ke PAUD, merupakan salah satu bentuk proses sosialisasi pada usia dini bagi anak-anak di luar lingkungan keluarga. Dengan adanya PAUD kesadaran masyarakat akan pentingnya pendidikan semakin kuat. Pendidikan sudah menjadi bagian yang tidak terpisahkan dari keluarga dan masyarakat, khususnya komunitas adat
Giri Jaya dan masyarakat Indonesia pada umumnya.

Gambar 2

Bangunan PAUD, Tempat Anak Bersosialisasi

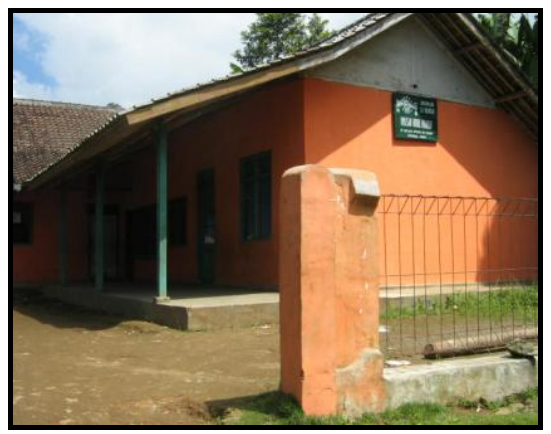

Sumber: Dokumen Penelitian 2009

Keluarga merupakan jalur pendidikan informal dimana kearifankearifan lokal mulai diterapkan dalam kehidupan anak-anak. Kearifankearifan tersebut dinyatakan dengan ungkapan-ungkapan tradisional. Ungkapan-ungkapan tersebut diungkapkan sesuai kebutuhan atau disesuaikan dengan situasi dan kondisi.

Untuk memperdalam dan menerapkan pendidikan agama, anakanak belajar ngaji atau baca tulis Alquran pada malam hari setelah magrib sampai tiba waktu shalat isya. Di tempat pengajian biasanya di rumah ustaz atau guru ngaji dan di mushola anak-anak belajar agama dari ustaz atau guru ngaji yang ada di Giri Jaya Padepokan.

Penanaman nilai dalam sistem penyebutan atau sapaan ke orang tua atau anggota keluarga lainnya. Sistem penyebutan atau sapaan pada komunitas adat Giri Jaya Padepokan sama seperti halnya pada masyarakat Sunda lainnya. Sifatnya umum, namun ada juga pada keluarga-keluarga 
tertentu yang menyebut dengan sapaan khusus ke orang tua. Misalnya ada menyebut dengan sebutan $a a$ ke bapak, padahal secara umum panggilan $a a$ sebenarnya panggilan kepada seorang kakak. Pada umumnya, pada komunitas adat Giri Jaya Padepokan menyebut ke bapak adalah bapak atau abah; sedangkan panggilan kepada ibu, ada yang menyebut dengan ibu, ema, mamah. Panggilan ke nenek, nini, atau ada juga yang memanggil dengan sebutan ema jadi sama dengan memanggil ke ibunya.

Pada masyarakat Giri Jaya, orang tua sangat besar peranannya dalam mengajar anak-anaknya berbicara dan berdoa. Hal ini disebabkan karena orang tualah yang pertama kali mengajarkan si anak untuk bersikap sopan santun dan berperilaku baik. Si anak harus belajar atau pembiasaan untuk hal-hal yang bersifat baik. Karena pembiasaan yang baik, merupakan bekal dan modal untuk pergaulan di lingkungan yang lebih luas lagi, seperti lingkungan masyarakat. Salah seorang responden mengatakan bahwa dalam mendidik dan mengajarkan anak harus leuleus jeujeur liat tali, artinya bahwa kita harus mengajarkan sesuatu kepada anak dengan lembut dan bijaksana.

Seorang anak yang memegang disiplin, antara lain harus taat pada pepatah yang disampaikan oleh orang tua atau orang yang dituakan oleh anak, misalnya anggota keluarga yang lebih tua selain ayah dan ibu. Pendidikan disiplin diri merupakan suatu proses yang harus dimulai sejak dini, atau sejak masa kanak-kanak. Oleh karena itu pendidikan disiplin pertama-tama harus sudah dimulai dari keluarga atau orang tua.
Selain proses penanaman nilai dan sosialisasi serta penerapan kearifan-kearifan lokal anak juga harus belajar disiplin. Penanaman disiplin merupakan salah satu bagian dari proses sosialisasi dan proses enkulturasi di dalam keluarga. Proses penanaman disiplin ini perlu diberikan kepada anak-anak untuk bekal si anak kelak. Proses penanaman disiplin merupakan proses pembelajaran bagi si anak. Belajar disiplin bagi anak mulai dari si anak bangun tidur sampai si anak tidur lagi.

Usia anak-anak adalah masa peka dimana berbagai proses perkembangan umumnya mulai berlangsung, termasuk penanaman disiplin yang berlangsung pada saat si anak mulai mau makan atau minum Tahap ini biasanya berlangsung pada saat si anak berusia 2 sampai 3 tahun baik bagi anak laki-laki maupun anak perempuan. Namun begitu, perkembangan anak tidaklah sama dalam satu keluaraga dengan anak pada keluarga lain. Begitu juga perkembangan anak perempuan dengan anak laki-laki tidak sama. Perkembangan anak mulai mau makan dan minum sendiri, umumnya karena keinginan meniru orang-orang dewasa yang ada di sekitarnya. Pada hakikatnya, disiplin yang ditanamkan pada anak, adalah upaya membiasakan anak untuk makan minum sendiri, agar anak tidak selalu bergantung pada ibunya. Di samping itu, membiasakan anak untuk mandiri.

Secara fungsional, upaya itu juga dimaksudkan untuk mengurangi beban tugas ibunya. Pada masyarakat Giri Jaya, sedikit sekali keluarga yang memelihara pembantu. Untuk meringankan pekerjaan di rumah 
tangga, para ibu umumnya mengandalkan peranan anak-anaknya yang sudah agak besar, terutama anak perempuan, baik untuk pekerjaan mengurus rumah tangga misalnya mencuci, memasak, serta mengasuh anak yang masih kecil. Sekalipun pola memandirikan anak untuk makan minum sendiri, merupakan upaya untuk meringankan beban tugas rumah tangga, namun dalam pelaksanaannya, si anak sejak awal dipolakan dengan menanamkan aturan-aturan disiplin tertentu.

Aturan-aturan

yang

membiasakan disiplin ditanamkan baik dalam hal sopan santun maupun tata tertib praktik makan minum, dan mandi. Hal-hal yang terkait dengan makan minum misalnya makan tidak boleh sambil berdiri atau makan tidak boleh sambil berbicara, atau makan tidak boleh berbunyi dan sebagainya, merupakan proses pendidikan untuk menanamkan kedisiplinan.

Berkaitan dengan sopan santun atau budi pekerti, si anak juga diberi pelajaran, misalnya bagaimana kita memperlakukan tamu yang harus dihormati, siapa pun tamu itu. Dengan demikian, kepribadian anak terbentuk menjadi sosok manusia dewasa dengan watak dan karakter kuat serta punya kepercayaan diri mandiri serta menjadi warga negara yang terhormat.

Disiplin juga diajarkan pada anak di saat usia dini anak. Di antara pelajaran disiplin pada anak adalah belajar shalat, di saat si anak sudah mulai bisa dan harus shalat. Bagi anak laki-laki mulai diajak shalat atau ke masjid oleh orang tuanya. Atau bagi anak perempuan disuruh shalat tepat pada waktunya. Belajar ngaji, merupakan salah satu pelajaran disiplin bagi anak-anak terutama bagi mereka yang beragam Islam. Si anak diberi pengertian tentang shalat yang merupakan kewajiban dan tidak boleh ditinggalkan, apabila meninggalkannya, termasuk perbuatan lalai. Bersamaan dengan belajar shalat, si anak diajari mengaji atau baca tulis Alquran. Biasanya mereka belajar mengaji pada malam hari. Ada yang mengaji di masjid atau ada juga yang mengaji di rumah ustaz, jadi si anak yang mendatangi rumah ustaz.

Seperti telah diuraikan di atas, bahwa gambaran masyarakat Giri Jaya merupakan komunitas adat yang agamis, maka para orang tua pun berusaha memberikan si anak pendidikan agama. Salah satu upaya orang tua dalam memberikan pendidikan agama di antaranya dengan mengantarkan si anak ke masjid atau mendatangi guru-guru ngaji untuk belajar agama, terutama belajar ngaji dan shalat. Upaya lain adalah dengan mengajak anak pergi ke masjid untuk shalat berjamaah, misalnya pada hari Jumat bagi anak laki-laki atau mengikuti pengajian-pengajian yang diselenggarakan oleh warga setempat. Dengan demikian, penghayatan dan pengamalan ajaran agama Islam mewarnai kehidupan komunitas adat Giri Jaya Padepokan.

Orang tua akan merasa senang dan bahagia, apabila anaknya manut akan perintah dan nasihat orang tuanya, terutama dalam hal keagamaan. Perkembangan seorang anak yang memperoleh pendidikan agama akan lain dengan perkembangan anak yang pendidikan agamanya kurang. Hal ini bisa dilihat dari perilaku si anak sehari- 
hari. Anak yang pendidikan agamanya kuat sangat santun, sedangkan si anak yang pendidikan agamanya kurang, perilakunya kurang menyenangkan, malah kecenderungan sangat mengkhawatirkan kedua orang tuanya. Oleh karena keburukan atau tabiat buruk tidak perlu dipelajari tetapi sangat mudah merasuki/merusak jiwa anak, sedini mungkin orang tua berusaha mendidik anak-anaknya dengan pengetahuan dan pengamalan agama. Tidak heran apabila ada orang tua yang mengungkapkan sebuah peribahasa yang ada kaitannya dengan pendidikan ini, orang yang berilmu tidak akan sama dengan orang yang tidak berilmu, orang yang berilmu derajatnya tinggi di hadapan Allah.

Sebagai orang tua, semestinya merasa bertanggungjawab terhadap anak, begitu penuturan seorang ibu. Oleh karena itu orang tua berusaha untuk mendidik anak-anaknya berperilaku baik dan santun. Dengan mengajari anak dengan kelembutan dan bijak, tidak berarti si anak tidak pernah ditegur atau dimarahi, karena tidak menutup kemungkinan si anak melakukan kesalahan-kesalahan. Seorang responden mengatakan, bahwa anak yang melakukan kesalahan tidak berarti harus dihukum, namun diberi pengertian bahwa apa yang telah dia lakukan itu salah dan tidak boleh diulang lagi.

Kadang orang tua berusaha mengajarkan kepada anak-anaknya berbahasa dengan tutur kata yang bagus terutama kalau ada tamu. Ini merupakan salah satu pendidikan santun kepada anak-anak. Pelajaran lain yang diberikan kepada anak-anak, selain kesantunan atau budi pekerti dan disiplin. Juga si anak diberi rasa tanggung jawab dan mandiri. Salah satu pendidikan mandiri pada anak adalah; si anak dibiasakan mengerjakan sesuatu dengan sendiri. Misalnya dalam hal makan, minum, mandi dan banyak juga hal lainnya.

Semua pekerjaan tersebut di atas pada awalnya dilakukan oleh ibunya namun si anak dilatih untuk bisa melakukannya sendiri. Salah seorang responden mengatakan bahwa anaknya belajar mandi sendiri sejak 5 tahun, begitu juga dengan tidur. Pada usia tersebut si anak sudah mulai tidur terpisah dari orang tuanya, sedangkan keluarga yang lain ada yang mulai dari usia anak 7 tahun. Hal tersebut memberi pelajaran kepada anak supaya mandiri. Hal ini berlaku bagi keluarga yang mempunyai tempat tidur lebih dari satu. Si anak diusahakan untuk tidur terpisah dari orang tuanya. Namun pada kenyataan di lapangan, tidak setiap keluarga atau umpi mempunyai tempat tidur atau kamar yang banyak. Kadang mereka tidur dalam satu kamar tidur. Mereka tidur rame-rame dalam satu kamar, karena kondisi memungkinkan begitu.

Dalam mendidik anak, si ibu lebih dominan dalam mengurus anakanak. Hal ini disebabkan si ibu lebih sering tinggal di rumah menunggui anak-anak. Di lingkungan Desa Giri Jaya, rata-rata satu keluarga terdiri atas 4 atau 5 anggota keluarganya. Oleh karena itu, bagi satu keluarga yang mempunyai anak lebih dari satu, biasanya dalam mengurus kelangsungan hidup dalam rumah tangga dibantu oleh anaknya, misalnya dalam hal mengasuh anaknya yang masih kecil, orang tua biasanya membebani anaknya yang lebih besar untuk mengasuh adiknya. 
Gambar 3

Mengasuh sambil bermain
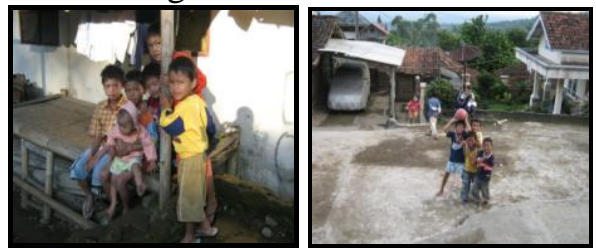

Sumber : Dokumen Penelitian 2009

Dengan begitu, pekerjaan si ibu terasa ringan karena dibantu oleh anaknya. Si anak juga merasa senang mengasuh atau mengajak main adiknya, karena mereka bisa membantu ibunya juga bisa sambil main. Bagi sebagian anak-anak, baik itu anak lakilaki maupun anak perempuan, pekerjaan mengasuh adalah waktu bermainnya. Anak-anak di lingkungan komunitas adat Giri Jaya Padepokan bisa dengan bebas mengekspresikan dirinya dalam bermain. Bagi mereka, bergantinya suatu permainan merupakan waktu istirahatnya. Mereka biasa bermain di halaman rumah, baik itu di halaman sendiri maupun halaman tetangga, yang halamannya luas. Di lokasi penelitian, cenderung masih banyak lahan yang luas untuk tempat anak-anak bermain.

Apalagi di lingkungan komunitas adat Giri Jaya Padepokan, lahan pesawahannya masih luas dan banyak anak-anak yang memanfaatkan sawah sebagai tempat bermain. Mereka sudah terbiasa dengan lingkungan pesawahan, karena sehari-hari kegiatan masyarakat Giri Jaya Padepokan bergelut dengan kegiatan di sawah. Sehingga tempat bermain anak-anak tidak terbatas di lingkungan sekitar pekarangan rumah saja.

Komunitas adat Giri Jaya Padepokan sebagian besar hidup dari hasil pertanian atau bercocok tanam. Terkadang anak-anak di Giri Jaya Padepokan membantu orang tuanya bekerja di sawah. Selain dapat meringankan pekerjaan orang tua, kegiatan ini merupakan pembelajaran 'life skill' atau pendidikan kecakapan hidup yang akan menjadi bekal bagi anak yang bersangkutan saat memasuki kehidupan orang dewasa di masyarakat.

\section{Gambar 4}

Seorang ibu dan anak

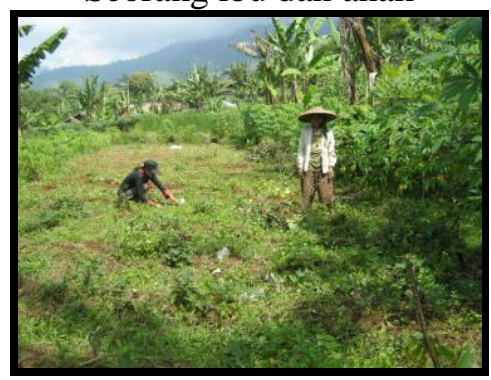

Sumber : Dokumen Penelitian 2009

\section{Penanaman Nilai Budaya}

Pada umumnya, sebagian besar warga Desa Giri Jaya khususnya komunitas adat Giri Jaya Padepokan menggunakan paraji dalam membatu persalinannya. Seorang paraji mempunyai peranan penting di lingkungan komunitas adat Giri Jaya, karena parajilah yang banyak mengatur dan merawat dalam pengurusan bayi. Adapun perawatan bayi tersebut, tidak hanya setelah si bayi dilahirkan, namun pada saat bayi itu masih dalam kandungan. Oleh karena itu, perhatian orang tua terhadap anak ada sejak anak tersebut masih dalam kandungan. Masyarakat percaya kepada paraji, bahwa selama masa mengandung, orang tua terutama ibu yang mengandung harus banyak menjalankan pantangan-pantangan. Hal 
itu untuk menjaga agar keadaan bayi dalam kandungan baik dan sehat, tidak terkena penyakit dan gangguan apaapa. Oleh karena itu, untuk menjaga hal-hal yang tidak diinginkan, si ibu mengadakan semacam selamatanselamat atau disebut juga upacaraupacara.

Komunitas adat Giri Jaya Padepokan sudah mengenal adat kebiasaan tersebut secara turun temurun. Kebiasaan itu diteruskan sampai sekarang. Adat istiadat yang diwariskan leluhurnya pada komunitas adat Giri Jaya masih dipelihara dan dihormati, di antaranya adalah yang berkaitan dengan lingkaran hidup manusia dari mulai lahir sampai meninggal. Lingkaran hidup tersebut disebut sebagai daur hidup. Dalam dalam daur hidup manusia, dikenal adanya upacara-upacara yang bersifat ritual adat, seperti upacara adat pada masa-masa kehamilan, kelahiran, anak-anak, perkawinan, dan kematian.

Upacara daur hidup adalah upacara-upacara yang dilaksanakan dengan tibanya seseorang pada tahapan kehidupan berikutnya dalam lingkaran kehidupannya. Sejak seseorang itu masih di dalam kandungan telah dilakukan berbagai upacara. Tujuan upacara antara lain untuk menjaga keselamatan janin yang sedang dikandung maupun calon ibu yang sedang mengandung dan juga seluruh anggota keluarga yang terkait dalam ikatan keluarga.

Upacara yang dilaksanakan pada saat bayi dalam kandungan biasanya ketika si bayi berusia 4 bulan , 7 bulan dan juga 9 bulan. Pada awalnya orang tua dulu mengadakan upacara pada saat usia bayi tujuh bulan dalam kandungan. Namun sekarang kecenderungan orang- orang melaksanakan upacara pada saat kehamilan menginjak empat bulan, karena pada usia kehamilan empat bulan itulah saat ditiupkannya roh pada jabang bayi oleh Allah SWT. Biasanya pelaksanaan upacara mengandung empat bulanan ini mengundang pengajian untuk membacakan doa selamat, biasanya doa nurbuat dan doa lainnya agar bayinya mulus, sempurna, sehat, dan selamat.

Namun pada umumnya komunitas adat Giri Jaya melaksanakan upacara tersebut di saat usia kandungan 7 bulan, karena pada usia kandungan ini si bayi sudah matang, dan harus dijaga, kelangsungan hidupnya. Upacara tujuh bulan disebut juga upacara tingkeban.

Upacara Tingkeban adalah upacara yang diselenggarakan pada saat usia kandungan 7 bulan. Hal itu dilaksanakan agar bayi yang di dalam kandungan dan ibu yang melahirkan akan selamat. Tingkeban berasal dari kata tingkeb artinya tutup, maksudnya si ibu yang sedang mengandung tujuh bulan tidak boleh bercampur dengan suaminya sampai empat puluh hari sesudah persalinan, dan jangan bekerja terlalu berat karena bayi yang dikandung sudah besar, hal ini untuk menghindari dari sesuatu yang tidak diinginkan. Seperti halnya pada upacara empat bulanan, di dalam upacara ini juga diadakan pengajian, biasanya membaca ayat-ayat Alquran, yang dibaca biasanya adalah surat Yusuf, surat Lukman dan surat Maryam.

\section{PENUTUP}

Pola pengasuhan anak yang merupakan proses sosialisasi pada 
komunitas adat Giri Jaya Padepokan, menjadi bagian yang tidak bisa dipisahkan dari budaya masyarakat tersebut. Keluarga sebagai unit sosial terkecil, tempat dimana seorang anak tumbuh dan berkembang dan berinteraksi di awal kehidupannya. Keluarga juga memegang peran yang sangat penting menuju proses sosialisasi yang lebih luas bagi anakanak ketika ia beranjak dewasa dan bergaul dengan individu lainnya di dalam maupun di luar lingkungan masyarakat.

Di lingkungan komunitas adat Giri Jaya Padepokan, dalam pola pengasuhan anak sangat bergantung pada peranan keluarga inti atau nuclear family, meskipun anggota keluarga lain seperti nenek, kakak, paman, bibi sering membantu dan dapat mewarnai atau mempengaruhinya. Peranan ibu dalam mengasuh anak bagi keluarga Sunda, dalam hal ini pada komunitas adat Giri Jaya Padepokan adalah sangat penting. Sepanjang hari dan bahkan malam hari mulai bangun tidur sampai si anak tidur lagi bahkan selama tidur, anak selalu berada dalam pengawasan ibu. Namun hal tersebut, tidak berarti peran ayah tidak kelihatan fungsinya. Peran ayah biasanya tampak dan dapat mewarnai bahkan dominan dalam kehidupan suatu keluarga. Akan tetapi dalam kehidupan sehari-hari, anakanak lebih dekat dan intim dengan ibunya, hal ini disebabkan ibu lebih banyak di rumah menemani anak-anak dan ayah biasanya tidak berada di rumah, meninggalkan rumah sepanjang hari untuk mencari nafkah. Biasanya dalam kehidupan keluarga Sunda, seorang ayah selalu dikaitkan peranannya dengan pekerjaannya, jabatan kedudukannya, yang tentunya sangat berpengaruh terhadap seluruh kehidupan keluarga.

Pada komunitas adat Giri Jaya Padepokan, orang tua sangat besar peranannya dalam pembelajaran pada anak. Pertama kali, orang tua mengajarkan si anak untuk bersikap sopan santun dan berperilaku baik. Si anak harus belajar melalui pembiasaan untuk hal-hal yang bersifat baik, karena pembiasaan yang baik, merupakan bekal dan modal untuk pergaulan di lingkungan yang lebih luas setelah lingkungan keluarga, seperti lingkungan masyarakat.

Pada komunitas adat Giri Jaya Padepokan, diajarkan juga masalah disiplin. Penanaman disiplin pada komunitas adat Giri Jaya Padepokan merupakan salah satu bagian proses sosialisasi dan enkulturasi di dalam keluarga. Hasil dari pembiasaan dalam keluarga, anak akan memperoleh landasan yang kokoh berupa kebiasaan baik dan perilaku disiplin. Pendidikan disiplin merupakan suatu bimbingan yang bertujuan menanamkan pola perilaku tertentu, kebiasaan-kebiasaan tertentu, atau membentuk manusia dengan ciri-ciri tertentu, terutama untuk meningkatkan kualitas mental dan moral.

Pola pengasuhan anak yang berlaku pada komunitas adat Giri Jaya berlaku universal, dalam arti sistem atau pola pengasuhan yang berlaku pada umumya terjadi di masyarakat. Selajutnya pola pengasuhan sebagai proses sosialisasi itu dilanjutkan dalam bentuk pendidikan di luar rumah, baik yang bersifat formal maupun nonformal. Hal itu terlihat adanya sarana dan prasarana untuk 
meningkatkan pendidikan seperti adanya bangunan SD, SMP, dan ada juga PAUD. Untuk komunitas adat seperti Giri Jaya Padepokan, merupakan suatu kemajuan, karena di lingkungan yang relatif sulit dijangkau, tapi sarana tersebut tersedia.

Salah satu bentuk pola pengasuhan anak yang rutin dilaksanakan oleh komunitas adat Giri Jaya Padepokan, adalah hampir setiap anak yang ada di Giri Jaya Padepokan belajar mengaji, mulai dari belajar baca tulis Alquran dan praktik ibadah menurut agama Islam. Kemudian setelah mengaji, anak-anak langsung mengikuti latihan kesenian daerah, yaitu latihan memainkan alat kesenian Sunda atau gamelan. Hal ini bagus sekali sebagai program pengenalan budaya lokal / daerah dengan mengenalkan alat-alat seni yang merupakan salah satu unsur kebudayaan. Hal ini merupakan warisan budaya yang diwariskan secara turun temurun.

Pola pengasuhan ini, pada gilirannya pasti berperan besar dalam pembentukan karakter anak dalam perkembangan berikutnya. Oleh karena itu memberi kesempatan seluas-luasnya pada anak untuk mengembangkan semua potensinya adalah satu prinsip dasar dari satu pola pengasuhan yang sangat baik bagi pembentukan karakter anak. Orang tua, asisten, atau pun orang yang lebih dewasa jangan mengambil alih tanggung jawab anak.
Pemerintah perlu lebih serius lagi memberikan perhatian tehadap keberadaan komunitas adat sebagai warisan budaya. Salah satunya adalah komunitas adat Giri Jaya Padepokan. Warisan budaya merupakan aset yang luar biasa bagi keberadaan suatu bangsa.

\section{DAFTAR PUSTAKA}

Djuariah M Utja, dkk. 1993/1994. Pembinaan Budaya dalam Lingkungan Keluarga di Jawa Barat. Bandung : Depdikbud.

Fauzi Racman,M. 2009. Anakku, Kuantarkan Kau ke Surga. Bandung : Mizan Pustaka

J. Vredenbregt. 1983.

Metode dan Teknik Penelitian

Masyarakat. Jakarta PT Gramedia. 1983. JAKARTA.

Kusnaka A, Djuariah, M. Utja, dkk, 1991.

Pola Pengasuhan Anak. Bandung : Depdikbud.

Ria Andayani, S. 1998.

Dinamika Pola Pengasuhan Anak dalam Budhiracana. No. 5. Bandung : BKSNT

Siti Dloyana Kusumah. 2001.

Pembentukan Norma dan Nilai Baru dalam Pranata Keluarga, dalam Jurnal Penelitian. Edisi Oktober. Bandung : BKSNT. 